As an illustration, it is better to print $\sqrt{ }(a+b)$ than $\sqrt{a+b}$ in a line of type, since the latter involves irregular spacing between the lines. On the other hand, the second of these expressions is more readily grasped when it can be displayed in a separate line. With the notation now in general use, almost all the symbols required in mathematical work can be so adapted as to be manageable to the compositor. It is pointed out that symbols which are necessarily awkward in appearance are fortunately rare. The present pamphlet is mainly of interest to the professional mathematician, there being no mention of the special symbols employed in such wide offshoots as actuarial mathematics. It includes a collection of the symbols which (in the eyes of a compositor) are better avoided, also a list of the symbols forming part of the stock of an up-to-date mathematical printer.

\section{Science and Art in the Textile Industries}

Is a speech at the annual Conference of the Textile Institute at Leamington Spa on May 19, Dr. S. G. Barker discussed the general relation of science to industry. Dr. Barker cited the recent observation in physics that drops of one electrolyte in another when submitted to the action of an electric field exhibit the phenomena of lateral spreading, as an example of the truth that none can say what textile applications will follow even a remote discovery in physical science, or when and how such discoveries will be made. In regard to the concrete benefit of science to the textile industries, Dr. Barker asserted that most of the work has been pioneer in character, and that good foundations once well and truly laid are rarely seen again. Unfortunately, the rapid extension of the bounds of physical science in the last decade created an inferiority complex in the minds of many ordinary individuals. The new knowledge appeared so vast and confusing that the minority of experts and investigators responsible for it were placed on a pedestal and their dicta accepted without thinking. Not only did the majority of people fail to realise the significance of the discoveries thus made, but inevitably the discoverer himself was frequently unable to recognise the social or industrial value of his discovery.

IN Dr. Barker's opinion, the scientific worker must endeavour to provide at the moment more practical results if, when prosperity returns, opportunity is to be afforded for the long-range fundamental researches. Only so can we hope to diminish the disparity between our mechanical skill and our social wisdom, between our power over Nature and the mentality which dictates its use. The challenge thus offered to us affords fresh opportunities for the spirit of adventure and romance which already finds expression so frequently in scientific research; and in regard to the textile industries, Dr. Barker stressed the importance of linking science to art and seeking to develop products which possess the supremely important æsthetic appeal. The union of art with science should mean not the degeneration of craftsmanship, but the creation of a progeny which will be economic, utilitarian, artistic, and scientific.

No. 3269, VoL. 129]

\section{National Parks in America}

IN an article in The Christian Science Monitor of May 13, much interesting information is given of the growth of the National Park Service of the United States, and of the projects now under consideration. The inauguration of the first national park took place some sixty years ago, but the National Park Service of the Department of the Interior was established by law of Congress, approved on Aug. 25, 1916. Its objects are to promote and regulate the use of the federal areas known as national parks, monuments, and reservations, and "to conserve the scenery and the natural and historic objects and the wild life therein, and to provide for the enjoyment of the same in such manner and by such means as will leave them unimpaired for the enjoyment of future generations". Mr. Stephen Mather, the 'father' of the national parks, was the first director of the service, but in 1929 he was succeeded by Mr. H. M. Albright. At the present time, the service has the administration of 22 national parks and 36 national monuments, but many others are supervised by the Department of Agriculture and the War Department.

IN an interview, Mr. Albright referred to the establishment of the Branch of Research and Education of the National Park Service. This has already given much attention to the natural scientific phases of the educational work, which includes the development of the means of informing visitors in the simplest way of the interesting geological and biological features of the parks. Special attention is now being given to the historic aspect. Among the most important projects now being considered are those for national parks in Virginia, Kentucky, Michigan, and Florida. The proposed Shenandoah National Park is in the Blue Ridge Mountains, Virginia, and consists of an irregular strip of virgin forest, 66 miles long and 8-18 miles wide. For the Mammoth Cave National Park the State Legislature of Kentucky has already appropriated $1,500,000$ dollars for buying caves and properties in the area. The caves are said to have passages and chambers extending approximately 150 miles on different levels. The Michigan scheme relates to the wilderness area, 45 miles long and 5-9 miles wide, on the shores of Lake Superior and only a little more than twelve miles from the coast of Ontario. The area is called Isle Royale, and it is the home of large herds of moose and caribou. Of a different character is the area of 2000 square miles which it is proposed to preserve in the south and south-west of Florida. This area includes channels, lakes, and swamps bordered by groves and forests filled with tropical vegetation. Another project is to connect the eastern parks by an Eastern National Park-to-Park Highway, giving tourists approximately 2000 miles of road, nearly every mile of which runs through scenic or historic country.

\section{Natural Reserves in the Belgian Congo}

IT is well known that the King of the Belgians has played an active part in the development of scientific institutions in his country, and that he is a keen supporter of research. Among his other interests is the question of the protection of the flora and fauna, 